\title{
Biological activities: anti-infectious, antioxidant and healing of the vegetable species Jatropha multifida
}

\author{
Atividades biológicas: anti-infecciosa, antioxidante e cicatrizante da espécie vegetal Jatropha multifida \\ Actividades biológicas: antiinfecciosas, antioxidantes y cicatrizantes de la especie vegetal Jatropha multifida
}

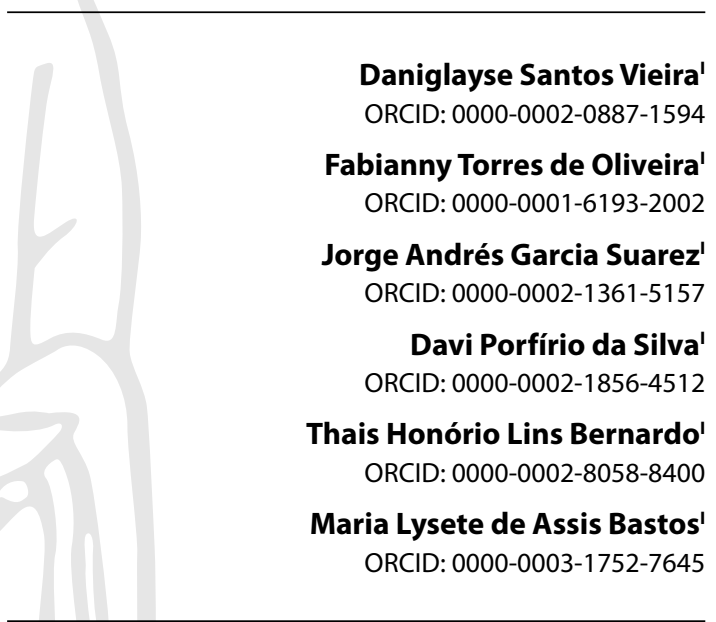

'Universidade Federal de Alagoas. Maceió, Alagoas, Brazil.

How to cite this article:

Vieira DS, Oliveira FT, Garcia Suarez JA, Silva DP, Bernardo THL, Bastos MLA. Biological activities: antiinfectious, antioxidant and healing of the vegetable species jatropha multifida. Rev Bras Enferm. 2021;74(2):e20200451. https://doi.org/10.1590/0034-7167-2020-0451

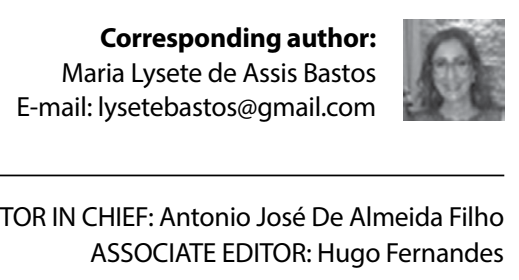

Submission: 08-28-2020 Approval: 11-05-2020

\begin{abstract}
Objective: to investigate the biological activities of interest to the health of Jatropha multifida plant species in published scientific literature. Methods: this is an integrative review, with searches between May and June 2019, using the descriptors, combined through the Boolean operator AND, Jatropha multifida, anti-infective agents, wound healing, cytotoxicity and antioxidants, in LILACS, BDENF, MEDLINE, SciFinder, Web of Science and Scopus databases and in the virtual libraries SciELO and ScienceDirect. Results: twelve publications were retrieved that showed nine biological activities. The antioxidant activity was reported in 04 (33.33\%) studies; antimicrobial and anticancer, addressed by 03 (25\%) and 02 (16.66\%); antiinflammatory, anti-melanin deposition, healing, antiophidic, purgative and anti-influenza, seen in $01(8.33 \%)$ each. Final considerations: although scarce, the published scientific production highlights the biological potential of $\mathrm{J}$. multifida and supports the need for further studies. Descriptors: Medicinal Plants; Anti-Infectives; Wound Healing; Anti-Inflammatories; Antioxidants.
\end{abstract}

\section{RESUMO}

Objetivo: investigar as atividades biológicas de interesse à saúde da espécie vegetal Jatropha multifida na literatura científica publicada. Métodos: trata-se de uma revisão integrativa, com buscas entre maio e junho de 2019, utilizando-se os descritores, combinado por meio do operador booleano AND, Jatropha multifida, anti-infective agentes, wound healing, cytotoxicity e antioxidants, nas bases nas bases de dados LILACS, BDENF, MEDLINE, SciFinder, Web of Science e Scopus e nas bibliotecas virtuais SciELO e ScienceDirect. Resultados: foram resgatadas 12 publicações que evidenciaram nove atividades biológicas. A atividade antioxidante foi relatada em 04 (33,33\%) pesquisas; antimicrobiana e anticancerígena, abordadas por 03 (25\%) e 02 (16,66\%); anti-inflamatória, anti-deposição de melanina, cicatrizante, antiofídica purgativa e anti-influenza, vistas em $01(8,33 \%)$ cada. Considerações finais: embora escassa, a produção científica publicada evidencia o potencial biológico de J. multifida e apoia a necessidade de mais estudos.

Descritores: Plantas Medicinais; Anti-Infecciosos; Cicatrização de Feridas; Anti-Inflamatórios: Antioxidantes.

\section{RESUMEN}

Objetivo: investigar las actividades biológicas de interés para la salud de la especie vegetal Jatropha multifida en la literatura científica publicada. Métodos: se trata de una revisión integradora, con búsquedas entre mayo y junio de 2019, utilizando los descriptores, combinados mediante el operador booleano AND, Jatropha multifida, anti-infective agentes, wound healing, cytotoxicity y antioxidants en las bases de datos LILACS, BDENF, MEDLINE, SciFinder, Web of Science y Scopus y en las bibliotecas virtuales SciELO y ScienceDirect. Resultados: se recuperaron 12 publicaciones que mostraron nueve actividades biológicas. La actividad antioxidante se informó en 04 (33,33\%) estudios; antimicrobiano y anticancerígeno, abordado por 03 (25\%) y 02 (16.66\%); antiinflamatorio, anti-depósito de melanina, cicatrizante, anti-fálico, purgante y anti-influenza, visto en $01(8,33 \%)$ cada uno. Consideraciones finales: aunque escasa, la producción científica publicada destaca el potencial biológico de J. multifida y apoya la necesidad de más estúdios.

Descriptores: Plantas Medicinales; Antiinfecciosos; Curación de Heridas; Antiinflamatorios; Antioxidantes. 


\section{INTRODUCTION}

Throughout its existence, human beings have been interacting with the environment in which they live, accumulating information about the environment and its infinite possibilities to act on it. Especially with regard to the use of medicinal plants, man has made empirical experiments that have improved their use and increase the framework of knowledge about these resources.

Plants have always been of great importance in cultural history, medicine and the food of societies around the world. The populations, through their healers and autonomous use, have accumulated experiences and vast knowledge in this regard ${ }^{(1)}$. Popular wisdom is rescued and exploited by ethnobotanical and ethnopharmacological studies, among others, which allow investigating and analyzing the use of plants for therapeutic purposes by a specific population group ${ }^{(2)}$.

In the national scenario, this process is catalyzed by the country's biodiversity. Brazil is among the countries that present the socalled megadiversity, with approximately 120,000 plant species, including the one belonging to Geraniales order, Euphorbiaceae family, which groups 317 genera and more than 8,000 species. The main centers of dispersion of Euphorbiaceas are America and Africa. In Brazil, 72 genera and about 1,100 species survive, including trees, shrubs, sub-shrubs and herbs ${ }^{(3-5)}$.

When discussing the approach to medicinal plants, it is worth mentioning the Brazilian National Policy on Medicinal Plants and Herbal Medicines (PNPMF - Politica Nacional de Plantas Medicinais e Fitoterápicos), approved by the Ministry of Health in 2006. This strategy is an essential part of public health, environment, economic development and social, showing itself as a cross-sectional element in the improvement of the Brazilian population's quality of life ${ }^{(6)}$.

In its $10^{\text {th }}$ edition, the Brazilian National List of Essential Medicines (RENAME - Relação Nacional de Medicamentos Essenciais) 2019, published in 2020, considered an official guiding instrument for the definition of public health policies regarding access to medicines within the scope of the Unified Health System (SUS - Sistema Único de Saúde), presents herbal medicines for use in Primary Health Care. Among those mentioned are artichoke (Cynara scolymus L.), peppertree (Schinus terebenthifolius), aloe vera (Aloe vera (L.) Burm. F.), cascara tree (Rhamnus purshiana), "espinheira-santa" (Maytenus officinalis), "guaco" (Mikania glomerata Spreng.), devil's claw (Harpagophytum procumbens), mint (Mentha x piperita L.), soy isoflavone (Glycinemax L.), plantago (Plantago ovata), willow (Salix alba L.) and cat's claw (Uncaria tomentosa) ${ }^{(7)}$.

Although not mentioned in this list, many species of Jatropha are widely used in folk medicine, being used with purgative actions, against gonorrhea, being diuretic, healing and anti-inflammatory and presenting themselves as sources of scientific investigation, since many species of this species have great chemical and biological potential. A bibliometric study, carried out on the basis of articles and patents in the last 10 years, revealed that the most cited species were J. curcas, having a very expressive number of citations (669), followed by J. gossypiifolia (37) and J. multifida (13)

Jatropha genus, belonging to Euphorbiaceae family, has 175 recognized species. The species can be monoecious (plant that produces male and female flowers, i.e., hermaphrodite) or dioecious (plants that produce male or female flowers in their structure), which include trees, shrubs and herbs ${ }^{(9-10)}$. This genus is considered morphologically diverse, presenting economic and ethnopharmacological importance. Jatropha species are common in northeastern Brazil, where they are well adapted to the dry climate (xerophilia) ${ }^{(11)}$.

J. multifida, object of research in this review, is known by the synonym Adenoropium multifidum or popularly by coral plant, coralbush, and physic nut. A small tree, whose red flowers with yellowish anthers look like small pieces of coral, has latex on the stem and reproduces by seed or seedlings. The fruit is a small capsule that, when ripe, turns yellow. J. multifida, from the Latin multifidus, means split in many parts, an allusion to the cracks observed in its leaves. This plant measures about $1.30 \mathrm{~m}$ in height and can reach 7 meters ${ }^{(12-13)}$.

Although it is known that using J. multifida in popular medicine is consolidated, there is a lack of research that justifies its use and certifies safety in its medicinal application. In this sense, faced with a plant of vast popular use and aiming to identify the biological activities performed by it, this integrative review seeks to answer the following question: which biological activities of interest to health are attributed to Jatropha multifida species?

\section{OBJECTIVE}

To investigate the biological activities of interest to the health of Jatropha multifida plant species in published scientific literature.

\section{METHODS}

This is an integrative literature review, which is presented as an investigation method, contributing to the deepening of knowledge on the investigated topic ${ }^{(14)}$, whose purpose was to gather and synthesize in a systematic and orderly manner the results of studies found in relation to the biological properties of interest to Jatropha multifida's health.

A well-conducted integrative review requires the same standards of rigor, clarity and replication as used in primary investigations ${ }^{(15)}$. Thus, for the construction of this review, six steps were taken: 1) theme definition and research question selection; 2) inclusion and exclusion criteria establishment; 3 ) identification of pre-selected/ selected articles and definition of information to be extracted; 4) assessment of selected studies; 5) analysis and interpretation of results; 6) knowledge review/synthesis presentation ${ }^{(9,14,16)}$.

\section{Theme definition and research question selection}

The research question definition is the first phase of this review, and scholars consider this step as guiding the conduct of a well-designed integrative review. The subject must be defined in a clear and specific way, and the guiding question, mentioned above, must be well delimited to allow easy identification of descriptors or keywords to search for articles ${ }^{(14)}$.

\section{Inclusion and exclusion criteria}

After determining the guiding question, articles that portrayed the theme and relevant to the object of study and guiding question, 
published and available electronically in full in the databases, in the last five years (2015-2019) and in Brazilian Portuguese, English and Spanish. Duplicate publications, previous notes, editorials, letters to the editor, reflective research and experience reports were excluded $^{(17)}$.

\section{Identification of articles and information extraction}

The following Health Sciences Descriptors (DeCS - Descritores em (iências da Saúde) in English and their combinations with use by the Boolean operator AND were established: Jatropha multifida (primary descriptor) and anti-infective agents, wound healing, cytotoxicity and antioxidants (secondary descriptors). It was decided to use the descriptors in English to expand the results obtained. This strategy did not exclude research published in Brazilian Portuguese and Spanish, as seen in the results, avoiding excessive redemption of duplicate publications ${ }^{(18)}$.

Article search took place between May and June 2019. For the survey of articles in literature, a search was carried out including concepts related to the biological potential of plant species studied in the Latin American \& Caribbean Literature in Health Sciences (LILACS), Bibliographic Database Specialized in Nursing (BDENF), Medical Literature Analyzes and Retrieval System Online (MEDLINE), SciFinder, Web of Science and Scopus online databases. Moreover, the Scientific Electronic Library Online (SciELO) and ScienceDirect virtual libraries were consulted. The databases were chosen because they incorporate investigations within science in general about the proposed theme or because they present the theme of this research inserted in the context of nursing.

A sample of 103 articles was obtained, of which 67 were previously excluded because they did not meet the inclusion criteria. The remaining 36 articles were submitted to reading titles and abstracts, for assessment of those that met the objective of the research and exclusion of duplicate articles, resulting in 14 articles identified as relevant for reading in full, in order to confirm their inclusion. The careful analysis of their references occurred in an attempt to identify articles that were not retrieved from the aforementioned search strategy ${ }^{(18)}$.

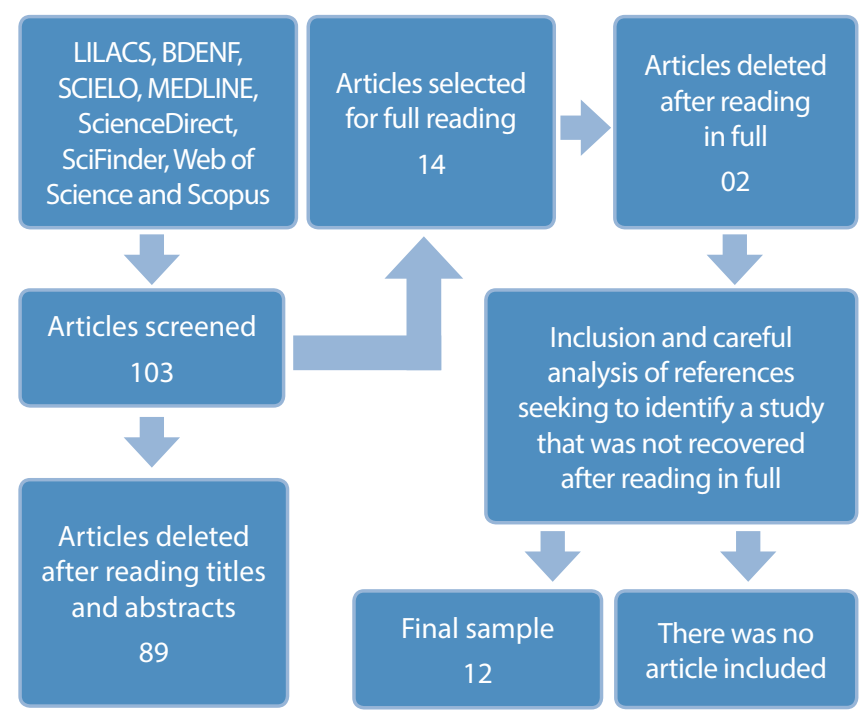

Figure 1- Flowchart of searches and selection of studies included in the review
After reading all articles and references in full, two articles were discarded, one for not responding to the purpose of the review and the other for not being available in full. There were no inclusions of new studies identified from analysis of references. The final sample included 12 publications, from which this review was carried out, as shown in Figure 1.

Then, in order to facilitate the understanding of results, an instrument for collecting and categorizing investigations was developed in Microsoft Word', based on Ursi (2005), contemplating the information to be extracted: title; journal; Qualis CAPES classification, considering the 2013-2016 quadrennium; year of publication; language; objective; methodological design/type of study; main results; biological activity; level of evidence ${ }^{(19)}$.

\section{Assessment of selected studies}

Using an organized approach to weigh the rigor and characteristics of each selected article, they were read in order to extract the information previously defined as necessary and consolidate it in the elaborated collection instrument.

The investigations were classified into levels of evidence, namely: level 1 - meta-analysis of multiple controlled studies; level 2 - individual research with experimental design; level 3 - investigation with quasi-experimental design as a study without randomization with a single pre- and post-test group, time series or case-control; level 4 - research with a non-experimental design such as descriptive correlational and qualitative research or case studies; level 5 - case report or data obtained systematically, of verifiable quality or program assessment data; level 6 - opinion of respectable authorities based on clinical competence or opinion of expert committees including interpretations of information not based on research ${ }^{(14)}$.

The journals in which the articles are published were categorized according to Qualis CAPES, which is a system used to classify the scientific production of graduate programs in relation to articles published in scientific journals. Qualis measures the quality of research and other types of production based on quality analysis of dissemination vehicles, i.e., scientific journals. CAPES provides a list with the classification of vehicles used by graduate programs for the dissemination of their production. In the 2013-2016 Classification, vehicles are classified into the following strata: $A 1$, higher; $A 2 ; B 1 ; B 2 ; B 3 ; B 4 ; B 5$ and $C$ - zero weight ${ }^{(20)}$. For that, nursing was selected in the assessment area, available on the Sucupira Platform.

The studies were also analyzed and compiled according to the biological activity performed by the plant, in the following categories: 1) anticancer; 2) antibacterial; 3) antioxidant; 4) antiinflammatory; 5) photoprotective; 6) healing; 7) antiophidic; 8) purgative; 9) anti-influenza ${ }^{(21)}$.

\section{Interpretation of results and synthesis of knowledge}

The step of interpreting the results is analogous to the discussion that occurs in primary investigations ${ }^{(22)}$. In this way, the information collected was compared, allowing the authors to discuss the evidence and assess possible gaps in knowledge.

Synthesis of knowledge occurred in a descriptive manner, seeking to detail the evidence recovered and offer the reader 
an instrument to deepen the studied theme, arranged in the categories of results and discussions.

\section{RESULTS}

The final sample of this review consisted of twelve $(n=12)$ scientific articles, selected by the inclusion and exclusion criteria previously established. Of these, six (6) were found in SciFinder, three (3) in ScienceDirect, one (1) in MEDLINE/PubMed, one (1) in Web of Science and one (1) in Scopus.

\section{Characterization of studies}

As for period of publication of articles (Chart 1), all were published in the last five years, with at least one publication each year. In 2016, there was the largest number of publications recovered, with a total of three $(25 \%)$ of the twelve, representing a quarter of the scientific production on the subject in the years studied.

Concerning language and country of origin, it is evident that all $(100 \%)$ articles that made up this review were published in English, and most, 07 (58.33\%), were from countries in Asia, 03 (25\%), from African countries, 01 (8.33\%), from the Americas, and another $(8.33 \%)$ was published by a group of researchers from America and Europe (Chart 1).

Regarding the type of study/corresponding level of evidence (Chart 1), it is observed that $10(83.33 \%)$ of articles are experimental with level of evidence VI and 02 (16.66\%) are for review with level of evidence IV, as they are descriptive investigations. It was found that $04(33.3 \%)$ articles were published in journals classified with the highest strata of Qualis CAPES, A1 and A2, while 06 (50.0\%) of these were published in journals classified as B1 and B2, thus demonstrating the high quality of articles that comprised this review. Only 02 (16.7\%) were within the classification between B4 and B5.

\section{Characterization of the biological activities of J. multifida}

Chart 2 shows the objectives of the studies selected in this review. In it, it is observed that $02(16.66 \%)$ assessed ethnobotanical knowledge of the species in question; 01 (8.33\%) aimed to identify the chemical structure of compounds isolated in the plant; another (8.33\%) investigated the mechanism of action, at the molecular level, of a substance from J. multifida with known bactericidal activity; 02 (16.66\%) researched the development of final products with the addition of the extract of the studied species (membrane to accelerate wound healing and a cream with antioxidant action); another 06 (50\%) carried out phytochemical screening plant and/or investigated at least one biological activity performed by it.

When analyzing the result of biological activities investigated by the selected articles (Chart 2), regardless of the methodology used, it was found that only $02(16.66 \%)$ assessed more than one plant activity, while the others (83.33\%) addressed only one activity of the species. Thus, of the 12 articles in this review, nine studied the biological activities of this plant.

Among the investigated biological activities, it was contacted that the antioxidant was present in 04 (33.33\%) studies, followed by antimicrobial in 03 (25\%) and anticancer in 02 (16.66\%). Antiinflammatory, anti-melanin deposition, healing, antiophidic, purgative and anti-influenza activities were investigated 01 (8.33\%) time. Thus, it appears that all of these in this review achieved the proposed objectives, and their results (Chart 2) identified nine biological activities of interest to J. multiida's health.

Chart 1 - Characterization of studies according to title, language, origin, type of study/level of evidence, journal, year of publication and Qualis CAPES, 2020

\begin{tabular}{|c|c|c|c|c|}
\hline No & Title & $\begin{array}{l}\text { Language/ } \\
\text { Article origin }\end{array}$ & $\begin{array}{l}\text { Type of study/ } \\
\text { Level of evidence }\end{array}$ & $\begin{array}{l}\text { Journal/Year/ } \\
\text { CAPES Qualis }\end{array}$ \\
\hline 1 & Cytotoxic macrocyclic diterpenoids of Jatropha multifida ${ }^{(23)}$ & English/China & Experimental $/ \mathrm{VI}$ & Bioorg Chem 2018/A1 \\
\hline 2 & $\begin{array}{l}\text { The importance of cyclic structure for Labaditin on its antimicrobial activity } \\
\text { against Staphylococcus aureus }{ }^{(24)}\end{array}$ & $\begin{array}{l}\text { English/Brazil } \\
\text { and Sweden }\end{array}$ & Experimental $/ \mathrm{NI}$ & $\begin{array}{l}\text { Colloids Surfaces B: } \\
\text { Biointerfaces/2016/A1 }\end{array}$ \\
\hline 3 & $\begin{array}{l}\text { Phytochemical screening, proximate analysis and free radical scavenging } \\
\text { activity of the roots extract of Jatropha multifida } a^{(25)}\end{array}$ & English/Nigeria & Experimental $/ \mathrm{NI}$ & $\begin{array}{l}\text { World J pharmaceutical } \\
\text { Res/2016/B5 }\end{array}$ \\
\hline 4 & $\begin{array}{l}\text { Antimicrobial, anti-inflammatory and antioxidant activities of Jatropha multifida } \\
\text { L. (Euphorbiaceae) }\end{array}$ & English/Togo & Experimental/ $\mathrm{VI}$ & Pharmacog Res./2016/B4 \\
\hline 5 & $\begin{array}{l}\text { Diterpenoids with thioredoxin reductase inhibitory activities from Jatropha } \\
\text { multifida }^{(27)}\end{array}$ & English/China/UK & Experimental $/ \mathrm{VI}$ & Nat. Prod. Res/2017/B1 \\
\hline 6 & Anti-melanin deposition activity and active constituents of Jatropha multifida stems ${ }^{(28)}$ & English/Japan & Experimental $/ \mathrm{VI}$ & J Nat Med./2019/A1 \\
\hline 7 & $\begin{array}{l}\text { Modification of polyethylene oxide-polyethylene glycol dimethacrylate hydrogel } \\
\text { film by the addition of Jatropha multifida sap for wound dressing application }{ }^{(29)}\end{array}$ & $\begin{array}{l}\text { English/ } \\
\text { Indonesia }\end{array}$ & Experimental $/ \mathrm{VI}$ & $\begin{array}{l}\text { AlP conference } \\
\text { proceedings/2019/B2 }\end{array}$ \\
\hline 8 & $\begin{array}{l}\text { Total flavonoid content and formulation of antioxidant cream stem from } \\
\text { jatropha multifida }{ }^{(30)}\end{array}$ & $\begin{array}{l}\text { English/ } \\
\text { Indonesia }\end{array}$ & Experimental/NI & $\begin{array}{l}\text { JPhysics: conference } \\
\text { series/2018/B1 }\end{array}$ \\
\hline 9 & $\begin{array}{l}\text { Antimicrobial, antioxidant and cytotoxicity potential of Manihot multifida (L.) } \\
\text { Crantz (Euphorbiaceae) }{ }^{(31)}\end{array}$ & English/Brazil & Experimental/NI & $\begin{array}{l}\text { An. Acad. Bras. } \\
\text { Ciênc.,/2015/B1 }\end{array}$ \\
\hline 10 & $\begin{array}{l}\text { Ethnopharmacological survey on medicinal plants used in snakebite treatments } \\
\text { in Western and Sabaragamuwa provinces in Sri Lanka }{ }^{(32)}\end{array}$ & English/Sri Lanka & Etnobotânico/IV & $\begin{array}{l}\text { J. Ethnopharmacol/2015/ } \\
\text { A2 }\end{array}$ \\
\hline 11 & $\begin{array}{l}\text { A comprehensive review of ethnopharmacologically important medicinal plant } \\
\text { species from Mauritius }\end{array}$ & $\begin{array}{l}\text { English/Mauritius } \\
\text { island }\end{array}$ & Etnobotânico/IV & $\begin{array}{l}\text { South African Journal of } \\
\text { Botany/2019/B1 }\end{array}$ \\
\hline 12 & $\begin{array}{l}\text { Anti-influenza virus activity of extracts from the stem of Jatropha multifida Linn. } \\
\text { Collected in Myanmar }{ }^{(34)}\end{array}$ & English/Japan & Experimental/ $\mathrm{VI}$ & $\begin{array}{l}\text { Complement Altern } \\
\text { Med./2017/B2 }\end{array}$ \\
\hline
\end{tabular}


Chart 2 - Characterization of studies according to objectives, biological activities and main results, 2020

\begin{tabular}{|c|c|c|c|}
\hline No & Objective & Biological activity & Main results \\
\hline 1 & $\begin{array}{l}\text { Identifying the structures of nine new macrocyclic } \\
\text { diterpenoids (1-9), Jatromultones Al, along with } \\
\text { eight known analogs (10-17) that were isolated } \\
\text { from the Jatropha multifidatrunks }\end{array}$ & Anticancer & $\begin{array}{l}\text { New compounds have been elucidated and screened for cytotoxicity } \\
\text { against five cancer cell lines, including a drug-resistant cell line. Of these, } \\
\text { seven compounds exhibited significant activity. The study provided a new } \\
\text { natural compound for the development of anticancer drug. }\end{array}$ \\
\hline 2 & $\begin{array}{l}\text { To investigate the mechanism of action at the } \\
\text { molecular level for Labaditin (Lo), a } 10 \text { amino acid } \\
\text { cyclic peptide from Jatropha multifida with known } \\
\text { bactericidal activity against Streptococcus mutans. }\end{array}$ & Bactericide & $\begin{array}{l}\text { Lo has been shown to be effective against Staphylococcus aureus. } \\
\text { Moreover, it does not require specific metabolic targets, which makes } \\
\text { cyclic peptides promising for antibiotics without bacterial resistance. }\end{array}$ \\
\hline 3 & $\begin{array}{l}\text { Assessing phytochemical screening, centesimal } \\
\text { analysis and scavenging activity of free radicals of } \\
\text { ethyl acetate, petroleum ether, chloroform, as well } \\
\text { as the crude root extract of Jatropha multifida. }\end{array}$ & Anti-oxidant & $\begin{array}{l}\text { Screening revealed the presence of carbohydrates, reducing } \\
\text { sugars, phenolics, flavonoids, glycosides, saponins and steroids. } \\
\text { The antioxidant property was more evident in chloroform extracts } \\
\text { compared to other fractions. }\end{array}$ \\
\hline 4 & $\begin{array}{l}\text { Investigating the antibacterial, anti- } \\
\text { inflammatory and antioxidant activities of the } \\
\text { ethanolic extract of J. multifida leaves. }\end{array}$ & $\begin{array}{l}\text { Antioxidant anti- } \\
\text { inflammatory } \\
\text { bactericide }\end{array}$ & $\begin{array}{l}\text { The antibacterial assay showed growth in vitro inhibition of } P \text {. } \\
\text { aeruginosa and } S \text {. aureus in a dose-dependent manner. The anti- } \\
\text { inflammatory effect occurred after } 3 \text { and } 5 \mathrm{~h} \text { after administration } \\
\text { of histamine and carrageenan, respectively. DPPH and FRAP tests } \\
\text { showed weak antioxidant activity. }\end{array}$ \\
\hline 5 & $\begin{array}{l}\text { Determining the thioredoxin (TrxR) inhibitory } \\
\text { activity of Jatropha, which is a potential target } \\
\text { for cancer chemotherapy with redox balance } \\
\text { and antioxidant functions. }\end{array}$ & Anticancer & $\begin{array}{l}\text { The chemical investigation of J. multifida led to isolation of nine } \\
\text { diterpenes (1-9). The results showed that two compounds ( } 6 \text { and } 7) \\
\text { had stronger inhibitory activities. Compounds ( } 5 \text { and 9) exhibited } \\
\text { moderate activity, while others were inactive. }\end{array}$ \\
\hline 6 & $\begin{array}{l}\text { Assessing the anti-melanin deposition activity } \\
\text { of J. multifida and to elucidate the mechanisms } \\
\text { of action of the isolated compounds. }\end{array}$ & $\begin{array}{l}\text { Anti-melanin } \\
\text { deposition }\end{array}$ & $\begin{array}{l}\text { The chloroform stem extract showed anti-melanin deposition activity } \\
\text { against induced melanogenesis. Fractionation and purification of } \\
\text { the main constituents led to the isolation of two coumarins ( } 1 \text { and } 2) \\
\text { and seven known lignoids (3-9). All isolates exhibited anti-melanin } \\
\text { deposition activities against the mouse melanoma strain (B16-F10). }\end{array}$ \\
\hline 7 & $\begin{array}{l}\text { Adding the J. multifida sap to the hydrogel } \\
\text { before crosslinking using electron beam. }\end{array}$ & Healing & $\begin{array}{l}\text { The PEO-PEGDMA crosslinked hydrogel film can be developed with } \\
\text { the addition of J. multifida sap with greater tensile strength using } \\
\text { electron beam irradiation. }\end{array}$ \\
\hline 8 & $\begin{array}{l}\text { Detecting the total flavonoid content and } \\
\text { antioxidant activity of the cream formulated } \\
\text { from the J. multifida stems. }\end{array}$ & Anti-oxidant & $\begin{array}{l}\text { The results showed that the extracts of J. multifida can be considered } \\
\text { as a natural antioxidant and can be useful to heal diseases resulting } \\
\text { from oxidative deterioration. A cream was formulated comprising } \\
5 \% \text { of extract using the fusion method, presenting good results and } \\
\text { suggesting potential for the development of cosmetics. }\end{array}$ \\
\hline 9 & $\begin{array}{l}\text { Assessing the in vitro antioxidant potential and } \\
\text { antimicrobial potential of this species against } \\
\text { strains of Gram-positive and Gram-negative } \\
\text { bacteria and fungi, known for infections in } \\
\text { humans. }\end{array}$ & $\begin{array}{l}\text { Antimicrobial and } \\
\text { antioxidant }\end{array}$ & $\begin{array}{l}\text { The antimicrobial activity was evidenced in the extracts (aqueous and } \\
\text { hexanic/leaves; methanolic/fruits) with minimum inhibitory concentration } \\
\text { (MIC) of } 39 \text { to } 2,500 \mu \mathrm{g} / \mathrm{mL} \text {. The best activity was against C. albicans (ATCC } \\
18804 \text { ) with MIC of } 39 \mu \mathrm{g} / \mathrm{mL} \text {. The cytotoxic activity with Artemia saline was } \\
\text { stronger for the methanolic extract of the leaves ( } \mathrm{CL}_{50} \text { of } 15.6 \mu \mathrm{g} / \mathrm{mL} \text { ). }\end{array}$ \\
\hline 10 & $\begin{array}{l}\text { Surveying the types of medicinal plant } \\
\text { materials, including the specific plant parts that } \\
\text { are available for snakebite treatment. }\end{array}$ & Antiophidic & $\begin{array}{l}341 \text { species of plants belonging to } 99 \text { families have been documented. } \\
\text { The largest number of plants reported was from Fabaceae family ( } 32 \\
\text { species). A J. multifida has been cited for the treatment of poisonous } \\
\text { snake bites in the form of bandages. }\end{array}$ \\
\hline 11 & $\begin{array}{l}\text { Highlighting species of medicinal plants that } \\
\text { deserve due attention regarding the assessment } \\
\text { of their pharmacological potential. }\end{array}$ & Purgative & $\begin{array}{l}\text { J. multifida popularly known as coral tree, has traditionally been } \\
\text { reported with purgative use. }\end{array}$ \\
\hline 12 & $\begin{array}{l}\text { Assessing the anti-influenza activity of extracts } \\
\text { from the stems of Jatropha multifida Linn }\end{array}$ & Anti-influenza & $\begin{array}{l}\text { Aqueous and chlorophoric extract from the stems of J. multifida } \\
\text { collected in Myanmar demonstrated stronger inhibition of viral } \\
\text { infection for H1N1 influenza. }\end{array}$ \\
\hline
\end{tabular}

\section{DISCUSSION}

\section{Scientific production}

The scientific production on the subject was still limited, especially in the Brazilian scenario. Of the 12 selected articles, only 02 (16.66\%) involve Brazil, one study being eminently Brazilian and another carried out by researchers from Brazil and Sweden, revealing a significant deficit in the number of Brazilian scientific productions that they investigated, in the last five years, the biological activities of J. multifida.
This plant species, popularly used as a medicinal plant, has dispersion reported by the literature in tropical and subtropical regions of Asia, Africa and America ${ }^{(35)}$, which may justify the totality of research involving countries in these continents. However, it should be noted that, when assessing the plant's origin in the studies, it was identified that countries where the species is not native have also aroused interest in investigations involving the genus Jatropha, for revealing itself as a source of molecules of pharmacological interest. In this family, there are genera and species that are distributed all over the world, mainly in tropical regions, being considered the third with the highest number of 
plant species in caatinga, presenting agricultural potential in the production of biofuel, animal food and medicinal use $\mathrm{e}^{(36)}$.

This is a plant that grows easily in poorly fertile soils, being cultivated in full sun, where it blooms better or in half shade, developing well in semi-arid and tropical climates, which corroborates the favorable growth of this species in Brazilian soils. In this sense, Brazilian studies, especially in the northeast, as it is a region still very lacking in health care, that people use these popular resources and has a geographical space conducive to the proliferation of J.multifida, are essential.

It is necessary to encourage further studies to obtain results in view of their biological properties in the Brazilian overview. This consideration is justified by the need to understand the composition and medicinal potential of local plants, since there are important variations that occur as a result of several factors. It is known that these plants and the chemical compounds that perform their biological activities are influenced by factors, such as seasonality, circadian rhythm, stage and age of development, temperature, water availability, UV radiation, soil nutrients, altitude, atmospheric composition and tissue damage ${ }^{(36)}$. Therefore, local studies are necessary to give legitimacy and security to use in popular medicine.

\section{Medicinal use}

In the $17^{\text {th }}$ century, the medicinal properties of plants were recognized as "active ingredients" contained within vegetables; since then, several of them have been cataloged and used as a source of biologically active natural products for drug synthesis ${ }^{(37)}$.

J. multifida has been popularly used to treat various conditions, such as fever, pain, infection, wounds, ulcers and various infectious skin diseases ${ }^{(38)}$. Thus, several studies have focused on the biological properties of the plant, and initial research shows that this plant species has shown antioxidant, antibacterial, antiinflammatory, antifungal, gastroprotective, healing, analgesic, immunomodulatory activity, among others ${ }^{(39)}$.

The researches compiled in this review covered nine biological activities, namely: antioxidant, antimicrobial, anticancer, antiinflammatory, purgative, antiophidic, anti-melanin deposition, anti-influenza and healing. Considering the consolidation of the popular use of J. multifida and with results as promising as the biological activities present in it, studies addressing activities not yet proven, side effects, economic viability and elucidation of compounds point to the possibility for developing biotechnologies that guarantee their use with efficiency and safety.

\section{Antioxidant activity}

Several degenerative diseases, such as cancer, coronary heart disease and premature aging, are influenced by oxidative stress induced by free radicals. Many plants have antioxidant compounds, such as flavonoids, which can protect cells against the degenerative effects of free radicals ${ }^{(37)}$.

The antioxidant activity of J. multifida was assessed by four studies in this review $(3,4,8,9)$. Although all of them proved antioxidant activity, three of them obtained more satisfactory results from this activity in plant extracts, while one of them resulted in weak antioxidant activity for the ethanolic stratum of J. multifida. One of the studies (8) aimed to detect the antioxidant potential of J. multifida stem and observed that its ethanolic extract showed antioxidant activity with $\mathrm{IC}_{50}$ of $72 \pm 0.01 \mu \mathrm{g} / \mathrm{mL}$. In this same research, a cream was formulated comprising $5 \%$ of extract using the fusion method, which presented good results, and, according to the authors, it may be a good potential for the development of cosmetic products ${ }^{(31)}$.

\section{Anti-cancer activity}

Currently, the search for new natural anti-tumor agents has become increasingly necessary, aiming at its greater effectiveness and less cytotoxic effect in normal tissues. The literature indicates that many natural products are available as chemotherapeutic agents against cancer, among the classes of compounds already tested with pronounced anticancer activity. We can mention the terpenes (sesquiterpenes, diterpenes and triterpenes), alkaloids, coumarins, lignans, flavonoids, tannins, stilbenes, curcuminoids, polysaccharides $^{(37)}$.

Diterpenes or diterpenoids are secondary metabolites of the terpene class consisting of 20 carbon atoms, corresponding to four isoprene units. They are mainly reported in Euphorbiaceae family, and these diterpenoids have attracted interest among researchers due to their wide range of biological activities such as cytotoxic and antimicrobial activities ${ }^{(23)}$.

A study carried out with branches and leaves of J. multifida led to the isolation of nine diterpenes (1-9), and these were screened for inhibitory activity against thioredoxinareductase ( $\operatorname{TrxR})$, which is a potential target for cancer chemotherapy with redox balance and antioxidant functions, revealing a possible anticancer activity of the species $^{(27)}$.

In a study investigating the presence of diterpenoids, Zhang ${ }^{(23)}$ sought to identify the structures of nine new macrocyclic diterpenoids (1-9), jatromultones Al, along with eight known analogs (10-17) isolated from J. multifida trunks. All diterpenoid compounds were screened for cytotoxicity against five cancer cell lines, including a drug resistant cell line, and seven compounds exhibited significant activity with IC values $_{50}$ below $10 \mu \mathrm{M}$.

\section{Antimicrobial and anti-inflammatory activity}

Studies on the antimicrobial effect of plant extracts are of great importance for health due to the cases of ineffectiveness related to bacterial resistance with allopathic agents and considering the use of these extracts as adjuvants in antibiotic therapies in which the pathogen is resistant to conventional treatments. Infection and inflammation are two factors widely discussed in the field of health, as they are related to poor prognosis of several pathologies.

The three studies in this review, which were intended to assess the antimicrobial activity of J. multifida, corroborate as shown in Chart 2, two of which directly investigated the antibacterial potential of plant extracts against microorganisms of interest to health, stating that J. multifida has this activity, which justifies its popular use ${ }^{(32-34)}$. One of the three articles, in addition to verifying the bactericidal action, also showed the anti-inflammatory activity in the highlighted plant, being the only investigation that proposed to investigate this activity among those that comprised the present review ${ }^{(32)}$. 
Another study addressed the mechanism of action at the molecular level for Labaditin (Lo), a 10-amino acid cyclic peptide from J. multifida, which has known bactericidal activity against Streptococcus mutans and against S. aureus, allowing to infer that the bactericidal activity of Lo is related to its interaction with the cellular plasma membrane, preventing the proliferation of these microorganisms at the cellular level, which reveals the antimicrobial action of the cyclic peptides found in that plant ${ }^{(34-35)}$.

\section{Anti-melanin deposition activity}

Skin color is determined by melanin, which plays a crucial role in protecting the skin and is produced naturally by melanocytes through a process known as melanogenesis. A study with chloroform extract from the J. multifida stem showed antimelanin deposition activity against melanogenesis in the mouse melanoma cell line. There was fractionation and isolation of the main constituents, and all compounds exhibited anti-melanin deposition activities against this specific melanoma strain ${ }^{(27)}$.

These results suggest that the featured plant may have potent skin lightening ingredients, which corroborates other studies that address the photoprotective power developed by several plant species. The result of a research entitled "Análise fitoquímica e atividade fotoprotetora de extrato etanólico de Euphorbia tirucalli $L$. (Euphorbiaceae)", belonging to the same family as Jatropha, suggests that its ethanol extract has a possible photoprotective effect ${ }^{(38)}$.

\section{Healing activity}

Medicinal plants have been an excellent alternative to antimicrobial resistance, a current health problem, since they have numerous advantages when compared to synthetic drugs. Moreover, terrestrial plants and their secondary metabolites play an important role as sources of innovative therapeutic agents for various conditions, including wound healing and infectious diseases $^{(39-40)}$.

In the searches carried out to compose this review, no investigations were found to directly assess the plant's healing activity, despite the vast majority of studies referring to the popular use of J. multifida for wound healing. As for the healing action, a research proposed to obtain a final product by modifying the polyethylene oxide and polyethylene glycol (PEO-PEGDMA) hydrogel film by adding Jlatex. multifida at $15 \%$ concentration, for application in wound dressings, in order to enhance hydrogel's healing action ${ }^{(37)}$.

\section{Antiophidic and purgative activities}

Two studies focused on the ethnobotanical knowledge of populations regarding J. Multifida use. This type of investigation is important, as it retrieves and records all popular knowledge about the use of plants, serving as a source of information to be researched and scientifically proven, to confirm biological activities of interest to the various areas of industry and enable the safe use of plant's active principles.

The survey of plants related to antiophidic activity brought to light scientific knowledge 10 species of Euphorbaceae family, among them J. multifida, for snake bite treatment. The documented plants, together with traditional knowledge, can be effectively used for isolation and characterization of antivenom for different snake species ${ }^{(38)}$.

In assessing ethnopharmacologically important medicinal plants in Mauritius, a study revealed the traditional purgative use of a plant popularly known as coral tree. Still, it brings the discussion that research focused on the safety profile of medicinal plants is also necessary to minimize the risk of side effects, adverse events, as well as the occurrence of herb-drug interactions among local inhabitants ${ }^{(33)}$.

\section{Anti-influenza activity}

In 2009, a new swine influenza A (H1N1) virus caused human infection and acute respiratory disease in Mexico, and spread globally. In the face of a health problem with a global impact, there were several studies with this focus, including investigating the biological activity of plants.

In 2017, researchers set out to investigate the anti-influenza effect of crude extracts from 118 medicinal plants, including J. multifida, collected in Myanmar in Asia. After conducting in vitro tests of the extracts of the stem of this plant, in Madin-Darby cells of canine kidney (MDCK), infected with the influenza virus (H1N1), it was verified the antiviral action of these extracts, which elects the referred plant as potential source of drugs for the development of anti-influenza compounds ${ }^{(34)}$.

\section{Study limitations}

The limitations are related to the existence of few publications specifically addressing the biological activities of the plant studied in the time frame of the last five years, which constitute the construction of more current knowledge. There was difficulty in discussing the biological activities of the plant grown in Brazilian soils, since only one article comprised the sample. Furthermore, the exclusion of studies that were not available in full and the possibility of not including articles that deal with the topic, but that have not been rescued through the descriptors used, become limitations.

\section{Contributions to nursing and the Unified Health System}

The research contributes to compile the knowledge already produced about the biological activities performed by J. multifida, of interest to health, since this plant is already consolidated in its use in populations for the treatment of various clinical conditions.

At the same time, it reinforces, given the few studies found mainly in Brazil, the need to conduct research that investigates the biological activities attributed to the plant, as well as unraveling bioactive molecules, quantifying constituents, mechanisms of action, toxicity tests, ensuring, with that, the development of biotechnologies that, in fact, prove to be as safe as allopathic treatments.

Using plants iempirically in the treatment of diseases is secular, and, in recent years, the scientific community has increased interest in proving the effectiveness of these products, aiming at the development of biotechnologies that can be applied safely in the field of health. In this perspective, this research consists of an overview of biological activities for human health, with a 
view to contributing to the expansion of the range of research on this plant species, so that it will be part, in the near future, of RENAME, in herbal form, for use in Primary Health Care/SUS.

The antimicrobial, antioxidant and healing activities of the plant in question are of particular interest to nursing, since it enhances the treatment of wounds, whose professional responsible for this treatment are nurses, within the health team; therefore, research focused on plants and their use in Primary Health Care should be increasingly encouraged.

\section{FINAL CONSIDERATIONS}

The analyzed studies showed that J. multifida can perform different biological activities, such as antioxidant, antimicrobial, anticancer, anti-inflammatory, purgative, antiophidic, anti-melanin deposition, anti-influenza and healing. Critical analysis of all articles selected for this integrative review allowed to show the wide and consolidated use in folk medicine of the plant known as Merthiolate, as well as the actions attributed to it and that must be investigated for confirmation by science.

However, this review identified a small number of searches on J. multifida, making it necessary to conduct additional investigations with a chemical approach and detailing the biological, pharmacological and clinical activities of the referred plant to better elucidate the mechanisms of action of its bioactive compounds. It was observed that although research shows good antioxidant and antimicrobial action of this species, the healing and cytotoxic potentials have not been fully proven.

These data provide support for further studies regarding the popular use of J. multifida, mainly in the treatment of wounds, pain and inflammation, so that it can be used safely, mainly in Primary Health Care, according to the PNPMF in SUS.

\section{REFERENCES}

1. Antonio GD, Tesser CD, Pires ROM. Contributions of medicinal plants to care and health promotion in primary health care. Interface (Botucatu). 2013;17(46):615-33. https://doi.org/10.1590/S1414-32832013005000014

2. Alves GSP, Povh JÁ. Estudo etnobotânico de plantas medicinais na comunidade de Santa Rita, Ituiutaba - MG. Rev. Biotemas. 2013;26(3):231-42. https://doi.org/10.5007/2175-7925.2013v26n3p231

3. Joly Al. Botânica: introdução à taxonomia vegetal. 13nd. São Paulo: Nacional; 2002. 808p.

4. Di Stasi LC, Himura-Lima CA. Plantas medicinais na Amazônia e na Mata Atlântica. 2nd ed. São Paulo: UNESP; 2002. 608p

5. Satiro LN, Roque N. A família Euphorbiaceae nas caatingas arenosas do médio rio São Francisco, BA, Brasil. Acta Bot Bras. 2008;22(1):99-118. https://doi.org/10.1590/S0102-33062008000100013

6. Ministério da Saúde (BR). Departamento de Assistência Farmacêutica Textos Básicos de Saúde: Secretaria de Ciência, Tecnologia e Insumos Estratégicos - Série B: Política nacional de plantas medicinal e fitoterápico [Internet]. Brasília: Ministério da Saúde; 2006 [cited 2020 Jan 16] (Textos Básicos de Saúde, n 1). Available from: https://bvsms.saude.gov.br/bvs/publicacoes/politica_nacional_fitoterapicos.pdf

7. Ministério da Saúde (BR). Departamento de Assistência Farmacêutica Textos Básicos de Saúde: Secretaria de Ciência, Tecnologia e Insumos Estratégicos - Relação Nacional de Medicamentos Essenciais: RENAME [Internet]. Brasília: Ministério da Saúde; 2019 [cited 2020 Mar 12] (RENAME). Available from: http://conitec.gov.br/images/Rename-2020-final.pdf

8. Perreira AS, Mendonça MS, Barbalho CRS, Alencar MSM, Souza CM. Prospecção científica e tecnológica do gênero Jatropha (Euphorbiaceae). Cad Prospec. 2015;8(2):355-64. https://doi.org/doi.org/10.9771/s.cprosp.2015.008.040

9. Leal-David HMS, Faria MGA, Dias JAA, Silva TF, Souza VMD, Dias RS. Análise de redes sociais na Atenção Primária em Saúde: revisão integrativa. Acta Paul Enferm. 2018;31(1):108-15. https://doi.org/10.1590/1982- 0194201800016

10. Santos MJ, Machado IC, Lopes AV. Reproductive biology of two species of Jatropha L. (Euphorbiaceae) in "caatinga", northeastern Brazil. Rev Bras Bot. 2005;28(2):361-73. https://doi.org/10.1590/S0100-84042005000200015

11. Rocha FAG, Dantas LIS. Atividade antimicrobiana in vitro do látex do aveloz (Euphorbia tirucalli L.), pinhão bravo (Jatropha mollissima L.) e pinhão roxo (Jatropha gossypiifolia L.) sobre microrganismos patogênicos. Holos. 2009;4(1):3-11, 2009. https://doi.org/10.15628/holos.2009.339

12. Levin $\mathrm{Y}$, Sherer Y, Bibi H, Schelesinger H, Hay E. Rare Jatropha multifida intoxication in two children. Selected Topics: Toxicology. 2000;19(2):173-75. https://doi.org/10.1016/s0736-4679(00)00207-9

13. Buch DR, Arantes AB, Campelo PMS. Verificação da atividade cicatrizante do exudato de folhas de Jatropha multifida L. Rev Bras Farm [internet]. 2008 [cited 2020 Apr 08];89(2):142-5. Available from: http://rbfarma.org.br/files/pag_142a145_verificacao_cicatrizacao.pdf

14. Mendes KDS, Silveira RCCP, Galvão CM. Revisão integrativa: método de pesquisa para a incorporação de evidências na saúde e na enfermagem. Texto Contexto Enferm. 2008;17(4):758-64. https://doi.org/10.1590/S0104-07072008000400018

15. Soares CB, Hoga ALK, Peduzzi M, Sangaleti C, Yonekura T, Silva DRAD. Revisão integrativa: conceitos e métodos utilizados na enfermagem. Rev Esc Enferm USP. 2014;48(2):335-45. https://doi.org/10.1590/S0080-6234201400002000020

16. Souza MT, Silva MD, Carvalho R. Revisão integrativa: o que é e como fazer. Einstein. 2010;8(1):102-6. https://doi.org/10.1590/s1679-45082010rw1134

17. Silva DP, Santos IMR, Torres PMF, Dantas HLL, Moreira RTF. O conhecimento de estudantes de graduação em Primeiros Socorros: uma revisão integrativa. Rev Port Saúde Soc [Internet]. 2019 [cited 2020 Mar 22];4(1):1055-1061. Available from: http://www.seer.ufal.br/index.php/ nuspfamed/article/viewFile/4526/5634 
18. Silva DP, Nunes JBB, Moreira RTF, Costa LC. Primeiros socorros: objeto de educação em saúde para professores. Rev Enferm UFPE. 2018;12(5):1444-53. https://doi.org/10.5205/1981-8963-v12i5a234592p1444-1453-2018

19. Ursi ES. Prevenção de lesões de pele no Peri operatório: revisão integrativa da literatura [Dissertação]. São Paulo (SP): Universidade de São Paulo, 2005.

20. Coordenação de Aperfeiçoamento de Pessoal de Nível Superior (BR). Classificação da produção intelectual. Qualis CAPES [Internet]. 2013 [cited $2020 \mathrm{Mar} 22]$. Available from: http://www.capes.gov.br/images/documentos/Relatorios_quadrienal_2017/Relatorio_quadrienal enfermagem.pdf

21. Ribeiro OMPL, Martins MMFPS, Tronchin DMR. Modelos de prática profissional de enfermagem: revisão integrativa da literatura. Rev Enferm Ref. 2016;10(1):125-33. https://doi.org/10.12707/RIV16008

22. Pompeo DA, Rossi LA, Galvão CM. Revisão integrativa: etapa inicial do processo de validação de diagnóstico de enfermagem. Acta Paul Enferm. 2009;22(4):434-8. https://doi.org/10.1590/S0103-21002009000400014

23. Zhang Jun-Sheng , Yao Z, Shen L, Abrar A, Gui-Hua T, Sheng Y. Cytotoxic macrocyclic diterpenoids from Jatropha multifida. 2018;80:511-18. https://doi.org/10.1016/j.bioorg.2018.06.025

24. Barbosa SC, Nobre TM, Volpati D, Ciancaglini P, Cilli EM, Lorenzón EM, et al. The importance of cyclic structure for Labaditinon its antimicrobial activity against Staphylococcus aureus. Colloids Surfaces B: Biointerfaces. 2016;148:453-59. https://doi.org/10.2016/j. colsurfb.2016.09.017

25. Ahomafor JE, Erharuyi O, Falodun A Okeri HA. Phytochemical screening, proximate analysis and free radical scavenging activity of the roots extract of jatropha multifida World J Pharmaceutical Res. https://doi.org/10.20959/wjpr201610-6802

26. Anani K, Adjrah Y, Améyapoh Y, Karou SD, Agbonon A, de Souza C, Gbeassor M. Antimicrobial, Anti-inflammatory and Antioxidant Activities of Jatropha multifida L. (Euphorbiaceae). Pharmacog Res. 2016;8(2):142-46. https://doi.org/10.4103/0974-8490.172657

27. Jian-Yong Zhu, Chun-Yang Zhang, Jing-Jing Dai, Khalid Rahman, Hong Zhang. Diterpenoids with thioredoxin reductase inhibitory activities from Jatropha multifida. J Nat Prod Res. 2017;31(23):2753-58. https://doi.org/10.1080/14786419.2017.1297441

28. Woo SY, Wong CP, Win NN, Lae KZW, Woo W, Elsabbagh AS, et al. Anti-melanin deposition activity and active constituents of Jatropha multifida stems. J Nat Med. 2019;73:805-13. https://doi.org/10.1007/s11418-019-01314-7

29. Haryanto F, Hardiningrum D, Swantomo D. Modification of polyethylene oxide-polyethyleneglycol dimethacrylate hydrogel film by the addition of Jatropha multifida sap for wound dressing application. AIP Conference Proceedings 2019;2085(1):020061. https://doi. org/10.1063/1.5095039

30. Franyoto YD, Kusmita L, Mutmainah, Agrena RD. Total flavonoid content and formulation antioxidant cream stem of jatropha multifida L. IOP Conf. Series: J Phys Conf Series. 2018;012130. https://doi.org/10.1088/1742-6596/1025/1/012130

31. Fabri LR, Sá DS, Perreira APO, Scio E, Pimenta DS, Chedier LM. Antimicrobial, antioxidant and cytotoxicity potential of Manihot multifida (L.) Crantz (Euphorbiaceae). An Acad Bras Ciênc. 2015;87(1):303-11. https://doi.org/10.1590/0001-3765201520130251

32. Dharmadasa RM, Akalanka GC, Muthukumarana PRM, Wijesekara RGS. Ethnopharmacological survey on medicinal plants used in snakebite treatments in Western and Sabara gamuwa provinces in Sri Lanka. J Ethnopharmacol. 2015;179:1 10-27. https://doi.org/10.1016/j. jep.2015.12.041

33. Suroowana S, Pynee KB, Mahomoodally MF. A comprehensive review of ethnopharmacologically important medicinal plant species from Mauritius. South African J Bot. 2019;122:189-13. https://doi.org/10.1016/j.sajb.2019.03.024

34. Shoji M, Woo S, Masuda A, Win NN, Ngwe H, Takahashi E, et al. Anti-influenza vírus activity of extracts from the stems of Jatropha multifida Linn. collected in Myanmar. BMC Complement Altern Med. 2017;96. https://doi.org/10.1186/s12906-017-1612-8

35. Gobbo-Neto L, Lopes NP. Plantas medicinais: fatores de influência no conteúdo de metabólitos secundários. Quím Nova. 2007;30(2):374-81. https://doi.org/10.1590/S0100-40422007000200026

36. Pereira Jr LR, Andrade AP, Araújo KD, Barbosa AS, Barbosa FM. Espécies da caatinga como alternativa para o desenvolvimento de novos fitofármacos. Flor \& Amb. 2014;21(4):509-20. https://doi.org/10.1590/2179-8087.024212

37. Ferreira MDL. Terpenos: potenciais agentes quimioterapêuticos obtidos de fontes naturais usados contra o câncer de pulmão [Monografia]. João Pessoa: Universidade Federal da Paraíba; 2014.

38. Orlanda JFF, Vale VV. Análise fitoquímica e atividade fotoprotetora de extrato etanólico de Euphorbia tirucalli L. (Euphorbiaceae). Rev Bras Plantas Med. 2015;17(4):730-36. https://doi.org/10.1590/1983-084X/14_012

39. Hirota BCK, Trevisan RR, Dias JFG, Miguel MD, Miguel OG. Fitoquímica e Atividades Biológicas do Gênero Jatropha: Mini-Revisão. Rev Visão Acad [Internet]. 2010 [cited 2020 Apr 08];11(2)103-12. Available from: https://revistas.ufpr.br/academica/article/view/21374/14094

40. Borges PMO. Avaliação da atividade tóxica e do perfil fotoquímico de Costus spicatus e Jatropha multifida [Monografia]. Anápolis: Instituto Federal de Educação, Ciência e Tecnologia de Goiás; 2016. 